\title{
A School for Modern Times: Mildred Louise fohnson and the Founding of the Modern School of Harlem
}

\author{
Deidre B. Flowers
}

Joan Hamburg Weisl wrote to Mildred Johnson (fig. I) on the Ethical Culture School's letterhead on January 28, 1944, requesting an interview with her former classmate. In the letter, Weisl reminded Johnson that they graduated together from the Ethical Culture School's Teacher Training Department (TTD) on June 4, I935. She wrote, "You've made lots of progress as I hear of your school all the time[;] mainly how fine it is." That school, founded by Johnson when she was twenty years old, was in its tenth year of educating Harlem's students. Begun with eight students in 1934, by 1944 Johnson's school enrolled I75 students with a long list of more whose parents were waiting to hear that a space had opened for their child. By comparison, Weisl noted her life's main accomplishment was having a daughter who attended the Ethical Culture School. This exchange might otherwise be mundane and uninteresting had it not been for the fact that Johnson was an African American woman, she was the first African American to complete the total course of study at Ethical Culture, Fieldston, and its TTD. ${ }^{\mathrm{T}}$

Deidre Flowers is assistant professor and interim director of Africana Studies at Queens College, New York.

I. Joan Hamburg Weisl to Mildred Johnson, January 28, I944, The Modern School box, The Modern School Collection, Manuscripts Archives and Rare Books Division, Schomburg Center for Research in Black Culture, New York Public Library (hereafter TMS Collection); Joan Hamburg

The Journal of African American History (Fall 2020) @2O2O ASALH. I548-I867/2020/IO5040003\$I0.00 All rights reserved. DOI: I0.I086/710665 


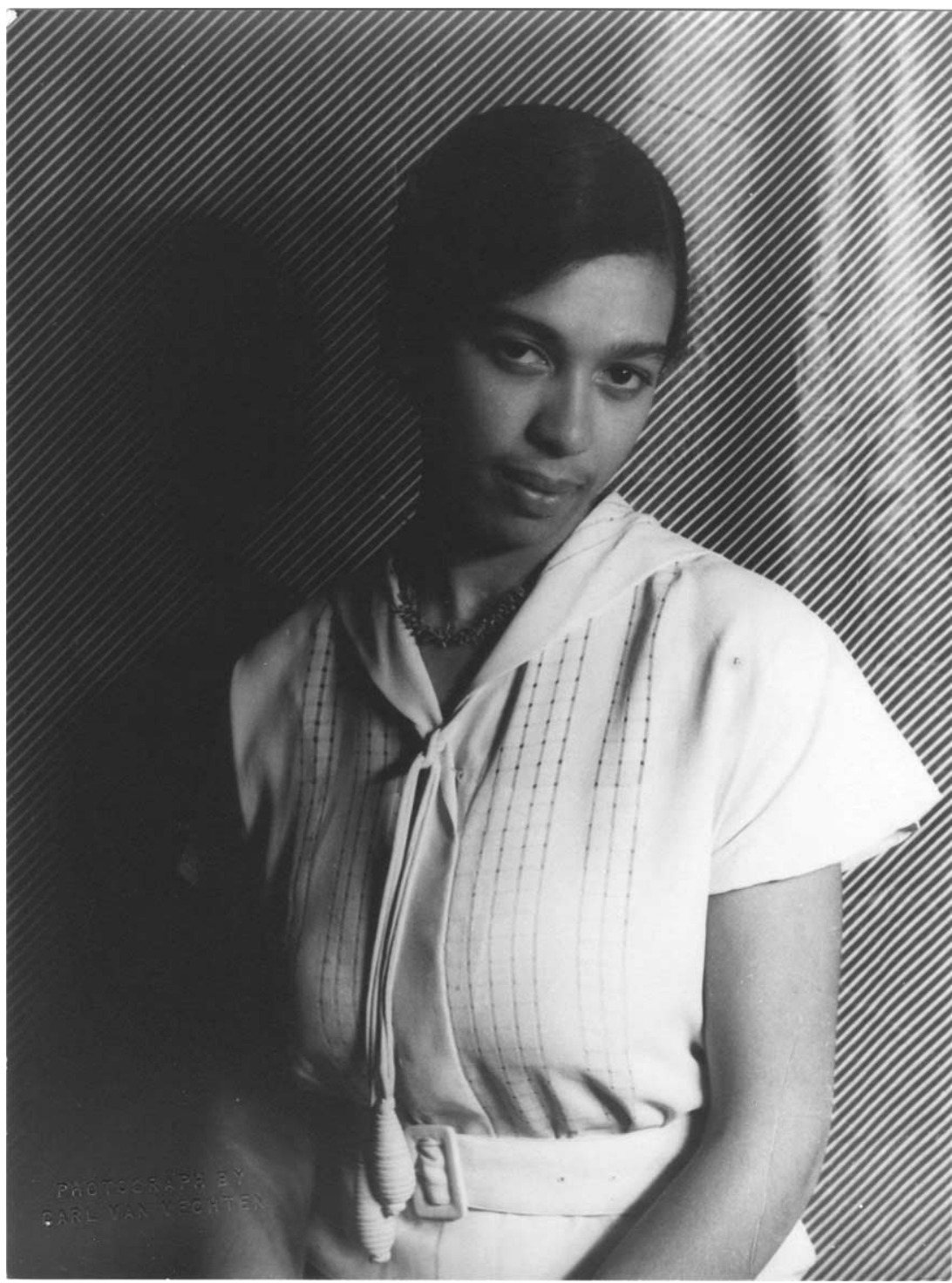

Figure I. Photo of Mildred Johnson, taken by Carl Van Vechten, June I6, I937. Photograph courtesy of James Weldon Johnson Collection, Yale University Archives, Image ID I095262.

Johnson's education and accomplishments occurred against the backdrop of the Harlem Renaissance and in the midst of the Great Depression. While still a student in the TTD, Johnson opened her own private school, The Modern

Weisl, "The Modern School in Harlem," Alumni Annual (Spring I944): II-I2, The Modern School box, TMS Collection. 
School (TMS), in I934. Weisl's I944 interview request hints at Johnson's unique and rare education accomplishment and the Harlem education institution that became her legacy. Published in the Spring 1944 issue of the Ethical Culture School's Alumni Annual, Weisl's article "The Modern School in Harlem" provided its readers an overview of Johnson's work during the school's first decade. Years later, New York Amsterdam News columnist Betty Granger Reid recalled Johnson's work at TMS and her dedication to "providing the kind of education that Harlem children weren't obtaining."”

This essay introduces the life and work of Mildred Johnson. She and her school are one example of a private grade school in the North that developed successful education methods and produced high-achieving African American students. Its success stands in stark contrast to the education that African American students experienced in twentieth-century New York City public schools. Johnson's life and work provide insight into the challenges faced by an African American woman in the North as she fought for the right to train as a teacher, complete her education, and pursue career opportunities in a northern private school. Encountering resistance forced Johnson to be strategic. Denial of a second student-teaching placement at any other New York City private school forced her to start and sustain her own independent education venture. Johnson's story is unique and important given what she accomplished as a young professional woman at a time when African American women had limited career opportunities and faced the effects of racism in the North, a region of the country assumed to be free of racism and discrimination. Those who lived there understood the Jim Crow North and the ways segregation and discrimination affected their lives. ${ }^{3}$ To craft this essay, I have drawn on a diverse collection of archival materials, including newspapers, personal papers, church, and educational records, to document Mildred Johnson's fascinating experiences as a community leader and institutional builder. ${ }^{4}$

\section{AFRICAN AMERICAN EDUCATION AND HARLEM \\ IN THE INTERWAR YEARS}

In the years following the Civil War, African Americans, women and men, took the initiative in creating their own schools to ensure that they could

2. Betty Granger Reid, “Conversation Piece,” New York Amsterdam Nerws, May 23, I970; "Education: New Yorker Pays \$70,000 for School Quarters,” fet Magazine, February 25, I954.

3. Brian Purnell and Jeanne Theoharis, The Strange Careers of the fim Crow North: Segregation and Struggle Outside the South (New York, 2019), 3.

4. The Modern School Collection and the Ethical Culture Fieldston School Records (ECFSR) were unprocessed when accessed in 20I8; as of July 20I9, the ECFSR are processed and the finding aid is under review. Ensuing footnotes identify the document location as it was at that time author accessed them. 
become participatory citizens in the American republic. Early examples of their collective efforts are evident in the presence of native and Sabbath schools found throughout the South when the Freedmen's Bureau surveyed the region during Reconstruction. ${ }^{5}$ By the early twentieth century, there remained an urgent need for access to formal schooling. Johnson's predecessors include Lucy Craft Laney, Charlotte Hawkins Brown, Mary McLeod Bethune, Nannie Helen Burroughs, and many others. These women founded and led southern education institutions that taught and inspired generations of African American students at a time when American society openly denied access to legal education opportunities. Historian Lauri Johnson points out that "historiographies of African American teachers . . . have largely focused on education in the South."6 Educators focus on the South because, prior to the Great Migration, the majority of those formerly enslaved, as well as their descendants, continued living there. After emancipation, newly freed African Americans worked to secure and exercise their citizenship rights even as retrenchment of social and political rights, granted by the Reconstruction Amendments, escalated. By the early twentieth century, African Americans sought freedoms denied them in southern states by migrating north, though it turned out to be no panacea. ${ }^{7}$

Johnson's initial goal was to fulfill a graduation requirement for her "Kindergarten-Primary Diploma." Once completed, Johnson then sought to prove that providing a quality education to Harlem's children was possible and used TMS for this purpose. Johnson and her teachers did this for sixty-five years. Her methods of instruction were based on the Progressive Education model that she experienced as a student at the Ethical Culture School and the teaching methods learned in the school's TTD. ${ }^{9}$ In 1919, Progressive Education was a "forward movement toward greater freedom and interest and joy in school life... [and] the expression of a new attitude toward childhood and youth. Freedom, interest, sympathy, trust, health" were the essentials. This style contrasted with public school education methods. Progressive $6-7$.

5. James D. Anderson, The Education of Blacks in the South, I865-1930 (Chapel Hill, NC, I988),

6. Lauri Johnson, "A Generation of Women Activists: African American Female Educators in Harlem, 1930-1950," fournal of African American History 89 (Summer 2004): 223-40.

7. Lucy Craft Laney founded Haines Normal and Industrial School (I883), Charlotte Hawkins Brown founded Palmer Memorial Institute (I902), Mary McLeod Bethune founded Daytona Literary and Industrial School for the Training of Negro Girls (1904), and Nannie Helen Burroughs founded the National Training School for Girls (I909).

8. "Ethical Culture Schools: Mildred Louise Johnson," Teacher Training Department diploma, June 4, I935, The Modern School box, TMS Collection.

9. Reuben R. Palm, "The Origins of Progressive Education," Elementary School fournal 40 (February 1940): 449 . 
educators "rejected the rigid pedagogy" used in public schools due to its "uniformity of curriculum, the stress of passivity, and teachers' reliance on rote memorization." iо

Progressive educators "called for learning experiences that fostered social, cultural, and intellectual meaning." Yet, they were criticized for "almost entirely" ignoring race and ethnicity while attempting to "enlist schools to build a better society." Essentially, they emphasized improving "the lives of poverty stricken [European] immigrants." Johnson's students' outcomes show that Progressive Education methods worked with African Americans. In using these methods with students in Harlem, Johnson advanced the notion that African American children could benefit from the Progressive Education teaching model and that inclusion of African American history and culture in a school's curriculum could benefit all students in the school. As educator Herbert Kohl notes, Progressive Education is "often ... confused with permissive education or libertarian education," which led to the present emphasis on "rigid, high stakes testing, teacher proof curriculum and strict discipline." Many note that current methods don't work well for all students. Educators and teachers continue to ponder if there is a way to be "supportive and nurturing" while delivering "effective instruction" and whether it is "possible to build humane, creative educational institutions that develop academic skills as well as self-confidence, self discipline and a cooperative, democratic spirit?"

Mildred Johnson established TMS in Harlem, a section of Manhattan, where migrants from the South and immigrants from the Caribbean comprised one of the city's expanding African American communities. Harlem became the principal residential location of Manhattan's African American population as they moved north from lower Manhattan. Before settling in Harlem, they called the Tenderloin District, on Manhattan's West Side between the twenties and the sixties, home. ${ }^{13}$ At the turn of the twentieth century, African Americans abandoned the "hostile" West Side, with its "overcrowded tenements" and "eruptions of anti-Negro" violence that made life difficult. Prior to the I920s, Harlem was "virtually [an] all-white neighborhood." African Americans moved there seeking better living conditions, and its newest residents viewed their new community as a refuge from the "horrid tenement conditions on the West Side."'r4

Io. Ibid., 442, 448, 449 .

II. Ruben Donato, The Other Struggle for Equal Schools: Mexican Americans during the Civil Rights Era (Albany, NY, 1997), II.

12. Jim Haskins, Diary of a Harlem School Teacher (New York, 1979), I6.

13. David Levering Lewis, When Harlem Was in Vogue (New York, 1997), 27; Jervis Anderson, This Was Harlem: 1900-1950 (New York, 1993), 8-12.

I4. Anderson, This Was Harlem, 3, 6I-62. 
Harlem's White residents believed the movement of African Americans into the neighborhood "took on the aspect of an 'invasion' ... of both their economic and ... social rights." When nineteenth-century New Yorkers referenced Harlem's boundaries, they spoke of Manhattan north of 86th Street. By the end of the nineteenth century, its southern and northern boundaries were IIoth and I55th streets, respectively; its western border was Morningside Drive and St. Nicholas Avenue, and its eastern border was the Harlem River. Present-day boundaries remain IIOth and I55th Streets on the south and north, the Hudson River on the west, and the Harlem River on the east. One former White resident woefully lamented in the mid-I920s, "I lived there all my life until not long ago, when I was squeezed out by the Negro population invading the old section." By I930, the majority of Harlem's White residents had "fled," leaving this strategically located Manhattan real estate to be occupied by African Americans. Its new residents were migrating north to escape oppressive living conditions in the South or were immigrants seeking opportunities that America, New York City, and Harlem offered. ${ }^{15}$

By the Great Depression, Harlem's new residents "had forged a dynamic political culture and infrastructure" that formed the basis for I930s and I940s protest movements. Shannon King notes that African American migrants intentionally built close-knit communities in the urban areas where they settled during the early twentieth century. He also posits that despite their concentration in Harlem and the need for social services, Black women and men were intentionally excluded "from preventive institutions and welfare agencies," in addition to being "targeted and brutalized ... in public and private urban spaces." Even with the rising interest in African American culture and arts, they "remained at the bottom rung of the city's economic ladder," with men working in the "service and transportation sectors," and women working as "domestics, garment workers, and launderers."

The school began operating during the interwar years in the midst of the Great Depression. This period was noted for the effects of "racial segregation and limited economic opportunity that plagued [Harlem during] the cultural flowering of the Harlem Renaissance."'17 In the early I930s, Harlem's African

I5. Ibid., 53, 59; Gilbert Osofsky, Harlem, the Making of a Ghetto: Negro New York, I890-I930 (Chicago, I97I), 234-35 n. I, ix, x; James Weldon Johnson, Black Manhattan (New York, I930), I46-47.

I6. Shannon King, Whose Harlem Is This, Anyway? Community Politics and Grassroots Activism during the New Negro Era (New York, 2017), 2-3, 7.

I7. Richard L. Hughes, "Harlem's Schools in the Great Depression: The Promise of the Agenda for Education in a Democracy in an Educational Dystopia," Education in Democracy: A fournal of the National Network for Educational Renewal (June 2012): 6. 
American residents experienced an unemployment rate that exceeded 60 percent, higher rates of preventable disease and mortality, and limited access to public and private financial resources. There were a number of problems in New York City's public schools, among them "dilapidated and overcrowded school buildings, large classes, and outdated curriculum materials." Residents also lacked "quality health care, social services, [and] recreational facilities." The year that Johnson founded TMS, 43 percent of Harlem's African American population received some type of governmental relief. ${ }^{\mathrm{I}}$ It was the only section of the city where the number of nursery schools was insufficient to meet the need. ${ }^{19}$ Prior to World War II, African American teachers represented just 2-3 percent of the city's public school teachers. Those employed were assigned to "underfunded schools in Harlem" and parts of Brooklyn, where overcrowded schools were operating on double, triple, and sometimes quadruple shifts and students were forced to share desks. ${ }^{2 \circ}$

While historical scholarship on women who started schools in the South are available, less is known about schools established and run by African American educators in northern cities, and even less is known about African American private school ventures. Johnson's founding of TMS is situated against a backdrop of social inequity, discrimination, and deprivation in an urban African American community. Discussing Johnson's work, Imani Perry observes: "What the Modern School accomplished in New York, or the Dunbar School in Washington, DC, or the Haines, Lincoln, and Palmer Institutes down south - that is, provide a superior education rivaling the best in the nation - reflected a widely held aspiration of black families for their children."21 Like James Anderson and other historians, Perry's statement highlights that African Americans valued and eagerly sought quality education for their children, along with their citizenship rights. ${ }^{22}$

I8. Johnson, "Generation of Women Activists," 224.

19. Hughes, "Harlem's Schools in the Great Depression," 7, I3; Lauri Johnson, "Making Democracy Real: Teacher Union and Community Activism to Promote Diversity in the New York City Public Schools, 1935-I950," Urban Education 37 (November 2002): 572-73; Dorothy Norman, "Harlem Mothers Slow in Asking Child Care," New York Post, February 6, I943, Admin Modern School box, TMS Collection; Sonya Michel, "The History of Child Care in the U.S.," https:// socialwelfare.library.vcu.edu/programs/child-care-the-american-history/; Johnson, "Generation of Women Activists," 227.

20. Johnson, "Making Democracy Real," 567-68, "Generation of Women Activists," 225.

2I. Imani Perry, May We Forever Stand: A History of the Black National Anthem (Chapel Hill, NC, 20I7), IOO.

22. Anderson, Education of Blacks in the South, 3; Dionne Danns and Michelle Purdy, "Introduction: Historical Perspectives on African American Education, Civil Rights, and Black Power," fournal of African American History Io० (Fall 2015): 573, 575, 582. 
Perry's comparison of Johnson's work with grade school students to that of southern high schools and teacher training schools during the early twentieth century places Johnson's work alongside that of other educators who led schools and inspired African American students to excel. These schools (such as Dunbar High School in Washington, DC; Haines Normal and Industrial School in Augusta, GA; Lincoln Institute of [Shelby County] Kentucky; and Palmer Memorial Institute in Sedalia, NC) are recognized models of secondary education excellence for African American students. Dionne Danns noted that segregated southern schools produced a number of successful graduates during the era of legal segregation. Johnson's school did so in the North during a similar period. ${ }^{23}$

In the aftermath of the 1935 Harlem Riot, Mayor Fiorella LaGuardia's Commission on Conditions in Harlem confirmed existing school grievances. Parents' complaints included antiquated and poorly equipped schools staffed with too many substitute and inexperienced teachers. These conditions persisted into the I960s, prompting psychologist Kenneth Clark to declare that "Harlem parents [have] complained about the poor quality of the schools in their community for over two decades" and that "conditions in Harlem schools ha[ve] only deteriorated." Further, he indicated, the intervening decades represented "a stage of educational decline" for African American students in the city's schools. ${ }^{24}$ The report, titled "A Report on the Conditions in the Schools in Harlem," painted a bleak picture of Harlem schools. ${ }^{25}$

Johnson's small private school played a role similar to schools opened and led by Laney, Brown, Bethune, and Burroughs in their respective communities. Also, much like private historically Black colleges and universities, TMS contributed to the education, uplift, and development of its students and the surrounding community. Many White Americans assumed that African Americans lacked the intellectual capacity to learn, while ignoring and denying their humanity, in addition to disregarding their rights as citizens. These actions stymied African Americans' efforts to participate in a democratic society. Johnson's

23. Perry, May We Forever Stand, Ioo; Dionne Danns, "Separate and Superior: Perspectives on African American Secondary Education," fournal of African American History Ioo, no. 4 (2015): $672-80$.

24. Adina Back, "Exposing the 'Whole Segregation Myth': The Harlem Nine and New York City's School Desegregation Battles,” in Freedom North: Black Freedom Struggles outside the South, I940-1980, ed. Jeanne Theoharis and Komozi Woodward (New York, 2003), 69.

25. Jennifer de Forest, "Tilting at Windmills? Judge Justine Wise Polier and a History of Justice and Education in New York City," History of Education 2uarterly 49 (February 2009): 84; "A Report on Conditions in the Schools of Harlem," I3, I7, I8, James Marshall Papers, box 3, folder I7, Municipal Archives, New York City Department of Records, Board of Education; Jennifer de Forest, "The 1958 Harlem School Boycott: Parental Activism and the Struggle for Educational Equity in New York City," Urban Review 40 (2008): 23, 24. 
work at TMS was based on her educational experience at the Ethical Culture School and Fieldston, their philosophy, and her experiences with noted figures of the Harlem Renaissance. Some of these figures had relatives that attended her school, including W.E.B. Du Bois, Duke Ellington, Countee Cullen, and Paul Robeson. Others were close enough to the family that she referred to them as aunt and uncle, including Fania Marinoff, Carl Van Vechten, Langston Hughes, and Zora Neale Hurston. ${ }^{26}$ To date, little scholarship has been published on Mildred Johnson. Daniel Perlstein has contributed a chapter, "Schooling the New Negro: Progressive Education, Black Modernity, and the Long Harlem Renaissance," to a volume edited by Ansley Erickson and Ernest Morrell. Perlstein discusses the centrality of the teaching profession to the growth of the Harlem Renaissance and provides a glimpse inside the TMS classroom in its early years. ${ }^{27}$ This essay responds to Danns's call to examine schools that "highlight the role of class and gender" and that didn't cater exclusively to elite classes. This analytical lens can be applied to TMS, because while TMS was a private school, from its inception students were welcomed from homes of varying socioeconomic and ethnic backgrounds. ${ }^{28}$

\section{EARLY LIFE AND EDUGATION}

I can't honestly claim an "up from slum life" beginning. Not even my grandparents were slaves. But I have struggled - known poverty, [and] felt prejudices in establishing [TMS]. ${ }^{29}$

Born May 25, I9I4, in Jacksonville, Florida, Mildred Louise Johnson was the only daughter of John Rosamond Johnson and Nora Ethel Floyd Johnson. ${ }^{3 \circ}$ She and her mother moved to New York City when her father returned from London, where he had served as director of music at the Hammerstein Opera House. Their new home, located at 4 and 6 West I3Ist Street, was the Music School Settlement for Colored People in Harlem (MSS), where Rosamond

26. "A Few Incidents from Mildred Grows Up during the Negro Renaissance," 7, or "When We Began," "Mildred," "Lots of Children," 4, The Modern School box, TMS Collection.

27. Daniel Perstein, "Schooling the New Negro: Progressive Education, Black Modernity, and the Long Harlem Renaissance," in Educating Harlem: A Century of Schooling and Resistance in a Black Community, ed. Ansley Erickson and Ernest Morrell (New York, 20I9), 3I-54.

28. Danns, "Separate and Superior," 679.

29. "Outline of TMS," I, The Modern School box, TMS Collection.

30. "Mildred Johnson Edwards Founded Harlem School," Vineyard Gazette (Martha's Vineyard, MA), August 23, 2007, https://vineyardgazette.com/obituaries/2007/08/24/mildred -johnson-edwards-founded-harlem-school?page=I; "Background Data Re: Mildred Louise Johnson Edwards, October I962," The Modern School box, TMS Collection. 
served as director. The MSS provided "cultural activities for African American children and young adults." Johnson was reared there among a close-knit middle-class family, and she frequently engaged with artists and intellectuals who were part of the family's social circle. ${ }^{{ }^{\mathrm{r}}}$

Johnson's earliest memory is of living at the MSS, located in "twin row houses" that she described as "a very large castle-like house where music was played all the time." ${ }^{22}$ The MSS was a community resource, offering dance, sports, and "space for concerts, lectures and social gatherings," along with any other activity deemed "wholesome recreation." ${ }^{33}$ In addition, the MSS offered "a weekly lecture series on various topics in music." 34 An only child, Johnson had no first cousins, as her Uncle James and Aunt Grace had no children. She recalled, "I had no brothers and sisters. I didn't even have a cousin." 35 Alive with a constant flurry of activity, Johnson describes the MSS as having "a different person playing piano, or the violin, or on a horn. There were people singing up high, down low, and just singing." On Saturdays, Johnson and her mother watched students practice. She was especially fond of watching dance and music classes. Her vicarious enjoyment of these classes is partially responsible for the incorporation of the creative arts in TMS's curriculum and its festival programs. It was also reflected in her later work with St. Philip's Episcopal Church, where, as the supervisor for religious education, she was responsible for producing and creating costumes for the church's various festivals. Johnson later provided similar services for two camps, James A. Farley and Dunroven. ${ }^{36}$ Too young to take classes, Johnson felt isolated, resulting in her desire to one day have "lots of children." 37 Johnson learned to read at the age of three from her Aunt Agnes and spent time with her father as he composed

3I. Kevin McGruder, Race and Real Estate: Conflict and Cooperation in Harlem I890-1920 (New York, 20I7), I48; "Impressive Rites for J. Rosamond Johnson," New York Amsterdam News, November 20, 1954, 2, box I03, folder Rosamond Johnson, JWJ Memorial Collection, Beinecke Rare Book and Manuscript Library, Yale University (hereafter JWJ Collection); "The New Home of the Music School Settlement 4 and 6 West I3Ist St.," box 2, folder 9, J. Rosamond Johnson Papers, Gilmore Music Library, Yale University (hereafter JRJ Papers); Perry, May We Forever Stand, 2-4; "J. R. Johnson Dies, Negro Song Writer," New York Herald Tribune, November 1954.

32. McGruder, Race and Real Estate, I48; "Lots of Children, or A Story of Mildred (An Autobiography of Mildred L Johnson written for children to read)," I, Admin Modern School box, TMS Collection.

33. McGruder, Race and Real Estate, $\mathrm{I} 48$.

34. Ibid.

35. "Lots of Children, or A Story of Mildred," I, Admin Modern School box, TMS Collection.

36. "Biography: Compiled by John Van Putten," 2, The Modern School box; and "Mildred Goes to Camp," 4, Admin Modern School box, TMS Collection.

37. McGruder, Race and Real Estate, I49. 
music and wrote musicals; this exposure enabled Johnson to develop an appreciation for music and a vivid imagination. In the absence of siblings and peers, her friends, she recalled, were "imaginary people who lived under the couch." She stated, "I had no one to play with. I was so lonely in the big house that I imagined that I lived with Willie and his imaginary friends. ${ }^{3_{3}}$

Given her father's and uncle's accomplishments, Johnson enjoyed a middleclass upbringing. It was their connection to Felix Adler, founder of the Ethical Culture Movement, that provided her entrée into the Ethical Culture and Fieldston Schools. Attendance in no way shielded her from the reality of being an African American student in an almost all-White private school, nor later as a Black woman desiring to break down well-established racial boundaries to become a teacher in one of New York City's private schools. Despite these obstacles, Johnson pursued her career objectives and created educational opportunities for her students.

Founded in 1878 by Felix Adler, the Ethical Culture School began as a free kindergarten. By I880, when elementary grades were added, the school educated poor and underprivileged children under the name the Workingman's School. Fifteen years later, oversight of the school transferred to the governing board of the Ethical Culture Society, and a secondary education program was added in I899. Within ten years, the school's academic reputation gained the attention of wealthy Jewish families, resulting in an expansion and tuition charges. ${ }^{39}$

Johnson entered Ethical Culture in the first grade. Nora Johnson intended to have her enter as a kindergartener. She recounted, in I932, "when I took you to school the first time, they were non-plussed. You could read, write and express yourself. Above all, this was unusual for a colored child. I took you to enter the Kindergarten and they put you in first grade."4० Johnson remembered, "I was very independent and had many of my parents' qualities, [I] enjoyed reading, writing, music, the theatre and just being alone." ${ }^{4 \mathrm{r}}$ By most accounts, she was a pleasant and talented student. Ethical Culture's Mildred Gignoux, Johnson's teacher, reported her academic progress to Rosamond and Nora, noting Mildred's academic progress was hampered due to frequent illness that year. Gignoux's letter highlights Johnson's work in English literature, indicating Johnson was "passing," "but in composition [her work is] most satisfactory,"

38. "Lots of Children, or A Story of Mildred," I, Admin Modern School box; and "When We Began," "Mildred," "Lots of Children," 2, The Modern School box, TMS Collection.

39. See "Ethical Culture Fieldston School History," https://www.ecfs.org/about-ecfs/history -of-ecfs; Howard B. Radest, Felix Adler: An Etbical Culture (New York, I998), II.

40. "Lots of Children, or A Story of Mildred," 7 - 8, Admin Modern School box, TMS Collection.

4I. "Why Did I Want to Teach?," 6, The Modern School box, TMS Collection. 
she continued, and "some of her writing has been lovely." Johnson was also passing history and French, and Gignoux made special note of Johnson's work in science, indicating "she is one of a very few girls who passed in Science and her standing in Art is excellent, the highest Art mark given in the class." ${ }^{2}$

Discussing her educational experiences at Ethical Culture, Johnson noted, "All of my schooling was in a white private school in the city." 43 "[It] exposes its students to not only an [accelerated] academic program but also a program heavily steeped in the cultural arts. Skills are also taught in many areas that usually are found in Vocational Schools. Therefore, when I completed their [high school], there was little I had not been trained in." 44 Johnson recalled that her education at Ethical Culture and Fieldston was "colored by a school which had a humanist religion infiltrating its policies." Humanist concerns focused on the worth and dignity of an individual as well as their "capacity for self realization through reasoning." Adler "emphasized moral education, psychological development, and integration of the creative and manual arts with academics." 45 Johnson concluded that "one hardly spends sixteen years in this type of environment without having certain attitudes rub off." ${ }^{46}$ From her privileged position, Johnson understood that her education experience was not common to most Harlem students. This understanding imbued in her a desire to share this type of education experience with the community that nurtured and sustained her.

Johnson understood the cultural influence of the New Negro Renaissance on her development. Jervis Anderson describes the Harlem Renaissance as "an artistic movement ... made up of chiefly writers." The movement "represented a break with the 'genteel' tendencies that had been dominant in black writing." Though not recognized until the mid I920s, the movement began during the early days of America's involvement in World War I and "during one of the early stages of black-militant activism in Harlem." ${ }^{47}$ Her father and uncle made significant contributions to the Renaissance. Along with other artists, they hastened the transformation of African Americans' image and acceptance of themselves, and they reinterpreted their history. The artists also advanced knowledge about African Americans' contributions to American history.

42. Mildred F. Gignoux to Mr. and Mrs. Rosmond [sic] Johnson, March 27, 1928, The Modern School box, TMS Collection.

43. "Outline of TMS," I, The Modern School box, TMS Collection.

44. Ibid.

45. See "Ethical Culture Fieldston School: Who We Are," https://www.ecfs.org/en/who -we-are/.

46. "Outline of TMS," 5, The Modern School box, TMS Collection.

47. Anderson, This Was Harlem, 195. 
Johnson believed in the intellectual capability of African American children. This belief places her in a class with other Black women educators who also believed in the ability of African American children to succeed academically and who structured the curriculum to achieve those ends. Her belief represents a radical departure from public school classroom environments where a predominantly White teaching staff often held low expectations for New York City's African American students' ability to achieve. Her belief and actions made a bold statement that African Americans had a culture, a sense of community, and were capable of sustaining and passing it on to future generations. Noting the importance of being raised during the Harlem Renaissance, Johnson observed, "I was part of this period in Black history because my family were among those who helped create the time when a Black man was judged and accepted for his contributions to society in the field of The Arts. ... This is why I had never met any prejudices until I entered [Ethical Culture's Teacher Training Department]."48

Growing up in an environment that affirmed her as a person, Johnson's exposure to racial prejudice was limited. Shielded from belittling ideas about her people allowed this creative and stimulating environment to bolster Johnson's self-esteem and confidence. Yet, having limited exposure did not negate her understanding of race or its impact on African Americans' lives. In addition to the affirming influence of the Harlem Renaissance on her upbringing, Johnson noted both her parents believed it was necessary to "master one's job and be better at it than anyone else," otherwise "one would be lost in the shuffle.” Johnson instilled a similar ethos in her TMS students as parents entrusted her and the teachers with the education and intellectual growth of their children. She reported, "I try to instill mastery into my Sixth Graders before they leave the school. They will be recognized, not if they are 'as good as,' but if 'they're better than." "49 The message was clear: Johnson expected TMS students to strive for excellence.

\section{ETHICAL GULTURE'S TEACHER TRAINING DEPARTMENT}

My paternal grandmother had been a teacher. My Uncle Jim had been principal of a school. My Aunt Agnes ... . had taught me to read when I was three. She had been a teacher. My father was a music teacher. What else could I be?50

48. Ibid.

49. Ibid., 6.

50. "Why Did I Want to Teach?” 4, The Modern School box, TMS Collection. 
As Johnson completed high school, she looked forward to attending Ethical Culture's Teacher Training Department to prepare for her chosen profession, following the family tradition. She recalled, "It was my real secret desire to be graduated from their TT Department and apply to teach in the school. What could they say? I was their product from beginning to end. I looked forward to hearing some squirm about employing a black teacher." 51 Johnson's statement suggests that although she did not regularly experience overt racism like the majority of African Americans in the city, she was keenly aware of the slights and indifference directed toward her as an African American woman in this predominantly White space. Johnson also understood the implications of her decision to seek admission to Ethical Culture's TTD. Her application forced the school to actualize the humanist values espoused in their educational philosophy and infused in their curriculum by taking a step toward dismantling racial discrimination in New York City's private schools. Nora Johnson pointed out that for twelve years Mildred "had to stand on her two feet and fight for her place in class and she certainly had to prove her right to be recognized." Nora was positive the TTD would admit Mildred. Encouraging her daughter, she stated, “Don't worry dear. From [the time of your admission] they literally took your brains apart every year to see what made you 'tick.' Don't worry, Mildred, they'll take you in Teachers Training." $5^{2}$

Some administrators and teachers at EC and Fieldston were surprised that Johnson intended to become a teacher. Self-assured, she declared her intention in $193^{2}$ when meeting with Dorothy Wright, an instructor in the TTD. Johnson was sure she did not want to attend Oberlin College, the school that her Fieldston counselors believed was a fit for her, since Oberlin was known to accept African American students. The Johnson family envisioned Mildred attending Uncle James's alma mater, Atlanta University. Financial constraints and her desire to teach ever since first grade influenced her final decision about her next steps. Johnson believed training to be a teacher at the institution she attended would best prepare her to become a teacher at that school or another private school in the city. ${ }^{53}$

During her interview, Wright queried Johnson about her anticipated high school completion. After being informed about Johnson's upcoming graduation from Fieldston in June 1932, Wright further inquired why the high school department allowed her to apply to the TTD, boldly questioning Johnson's academic acumen and place in society. Johnson simply stated, "I met all

5I. Ibid., 8.

52. "Lots of Children, or A Story of Mildred," 6, Admin Modern School box, TMS Collection.

53. Cally L. Waite, "The Segregation of Black Students at Oberlin College after Reconstruction," History of Education 2uarterly 4I (Autumn 200I): 344; "Lots of Children, or A Story of Mildred," 5, Admin Modern School box, TMS Collection. 
requirements." In this exchange, Johnson is forcing ECFS to consider the ideals it espoused and take action. Moreover, Johnson informed Wright that she had expressed an interest in attending the TTD upon entering Fieldston in I928. Johnson continued, "If I am not prepared, it's the school's fault. I've never been to any other school in my life. If my record isn't O.K. the school is to blame." ${ }^{44}$ Certainly, this elite private school could not, after twelve years of educating Johnson, now claim that she was not qualified to attend the TTD after she had excelled in this environment. In this exchange, Johnson challenged the inherent doubt of some leaders at ECFS in her capabilities. She does this in a subtle and genteel manner that confronted but did not antagonize, slyly questioning why Wright believed she would not be capable of completing the Teacher Training program and what made her different from its other applicants.

To Johnson's retort, Wright replied, "But the point is, my Dear, Teacher Training only prepares you to teach - and there aren't any colored teachers." The underlying presumption was that African Americans didn't teach in White private schools, so perhaps a public or Catholic school with African American students would be more suitable for Johnson. It is unclear which setting Wright was referring to regarding African American teachers, as their numbers were few in New York City's public schools' teaching force, and none taught in the city's private schools. Johnson stood firm; her sights fixed on teaching in a private school, specifically at Ethical Culture. She informed Wright that her plans were to finish TTD and begin teaching at Ethical Culture. "It would be nice to hear all of the excuses for not hiring me," she recalled. Shocked, Wright explained, "we've looked and looked but the colored people just aren't qualified." Johnson assured her that if admitted, "[I] will be prepared and qualified to be hired at Ethical Culture [and] the Fieldston School." ${ }^{56}$

Upon admission to the TTD, Johnson was assigned to "one of the most liberal teachers in the school," Ellen K. Donohue, who had been Johnson's first grade teacher. Donohue allowed her to lead most of the classroom's teaching activities; she was also allowed to move the class around the school using the elevator and take students up and down the hall. School administrators attempted to halt this activity, indicating that, "student teachers were not allowed to move groups of children." ${ }^{77}$ Since Johnson was the only student teacher engaged in this activity, both she and Donohue understood the implications

54. "Teacher Training Department Ethical Culture Schools, I933-1934," 4, box 157, folder 20, ECFS Records.

55. "Lots of Children, or A Story of Mildred," 5-6, Admin Modern School box, TMS Collection.

56. Ibid., 9; "Lots of Children, or A Story of Mildred," 9, Admin Modern School box, TMS Collection; Johnson, "Making Democracy Real," 567-68.

57. “Grade I (2)," October I925, I, box 5I, folder 29, Ethical Culture Fieldston School Records, New York Historical Society (hereafter ECFS Records); "Lots of Children, or A Story of Mildred," 9, The Modern School box, TMS Collection. 
of the administrative directive. It was to limit Johnson's influence on students and keep her in her proper place. Donohue made no modifications to Johnson's classroom responsibilities, allowing her to continue leading many of the class's activities. It appears that the administrator's perception was that Johnson's action as a teacher was incompatible with the role that an African American woman should play in a space for Whites. Donahue's action, or inaction, following ECFS's leadership's directive supported Johnson's stern position in exercising all responsibilities of her student teacher role in preparation for her future responsibility.

Ethical Culture's students enjoyed Johnson's classroom work and introduced her to their parents as their teacher. Perplexed upon encountering an African American woman, White parents often dismissed their children's excited utterances. Johnson recalled the day one student replied to her father's dismissal of Johnson. She told him emphatically, "Miss Johnson is my teacher even when [Miss Donohue] is in the room. She teaches me to read and helps me do number work[,] and reads to us, and everything[!]" After a brief pause, Walda Winchell looked at her father, Walter Winchell, a "well-known radio commentator," asking, "Daddy, why don't you think she's my teacher?"58 Johnson did not note Winchell's response.

In the spring semester of 1934, near the end of her Teacher Training assignment at Ethical Culture, placement decisions were made for the next school year. There was reportedly a concerted effort to locate a second private school to accept Johnson, thus allowing her to fulfill this final graduation requirement. The task was difficult, given the reluctance of local private schools to accept an African American woman as a student teacher. Ethical Culture informed Johnson that they were working to "persuade a private Catholic School to take you as a student teacher in September. We tried several of the private schools but they were afraid of what their parent-body might say. $" 59$

When applying to the TTD, Johnson was told that it was "foolish" to expect she would teach in a private school, since no "colored girls taught in private schools[,] or for that matter taught" in the I930s. This, she reports, was her "first real brush with prejudice." The accuracy of this statement is unlikely, given the fact that White Americans regularly discriminated against African Americans. These incidences may more accurately be described as times when individuals boldly and unapologetically displayed their prejudices directly to her without shame or remorse because Johnson boldly and unapologetically lived her life. In doing so, Johnson resisted staying in the prescribed place White Americans believed an African American woman belonged. Although

58. "Lots of Children, or A Story of Mildred," 9, The Modern School box, TMS Collection. 59. Ibid., Io. 
admitted and excelling academically, some Ethical Culture teachers saw Johnson's race and believed she was not in her proper place in their White space. Therefore, although admitted to train as a teacher, she was not, in their opinion, to be accorded the same professional responsibility or respect as White Teacher Training students. ${ }^{60}$

When enrolled, Johnson was the only "colored student" in the TTD. Recounting her experience in the program, Johnson revealed that her years there were "most successful" as she had the opportunity to frequently substitute when teachers were absent. Yet, she also reported "the administration of the TTD were most unhappy and put many blocks in my way." By June, as the school year ended, Johnson resolved that she had come too far and "wasn't going to be stopped." TTD leaders assured her the issue would be worked on "over the summer and [they] would surely find some place by the fall."

\section{SUMMER CAMP EXPERIENCE AND FOUNDING \\ GAMP DUNROVEN, SUMMER 1934}

Beginning at age ten, Johnson attended summer camps. Nora Johnson first allowed her to attend Camp Emetowa for two weeks in 1924. Thereafter, she attended this camp annually until I928, when St. Philip's opened Camp Guilford Bower, a coeducational camp - the second in the country - owned and operated by African Americans for their children. Leslie Paris notes that camps served the rich and the poor. Johnson recalled that during the I920s, "there were no camps for middle-class colored children . . . and there were very few camps for underprivileged [African American] children." Harlem's children primarily attended summer camps organized by the Fresh Air Fund (FAF) until the mid I920s, when the FAF reported it was difficult to place African American children with "private hosts." Scholar Stephen Robertson asserts that in I920s Harlem, the purpose of camps was to provide "a place for children when school was closed" because "Harlem offered little other than the streets." "62

First organized for boys in the late nineteenth century, the founders of summer camps "aspired to bring elite Christian boys into communion with nature

6o. "Outline of TMS," I, The Modern School box, TMS Collection.

6I. Ibid., 2.

62. Leslie Paris, "The Adventures of Peanut and Bo: Summer Camps and Early-TwentiethCentury American Girlhood," in The Girls' History and Culture Reader: The Twentieth Century, ed. Miriam Forman-Brunell and Leslie Paris (Urbana, IL, 20II), 92-93, IOI, IO6 n 57; Stephen Robertson, "Summer Camps for I920s Harlem," http://drstephenrobertson.com/digital harlemblog/maps/summer-camps-for-I920s-harlem/; Leslie Paris, Children's Nature: The Rise of the American Summer Camp (New York, 2008), 283. 
to address a pressing concern: the . . . enfeebling effects of an increasingly industrial and urban world on those middle- and upper-class white urban boys who were ... destined to lead the nation." Urban reformers also worried about working-class and immigrant boys, whom they imagined also required "better moral guidance." New York State "boasted more camps than any other [state]" a decade before Johnson began attending camp. Almost four hundred existed, with half "under private ownership" and the other "half run by organizations." By the I930s, the state had "more than eight hundred" summer camps, which "removed children from stifling urban apartments, the threat of health epidemics and 'artificial' leisure," teaching "acculturation and good citizenship."

St. Philip's Episcopal Church purchased Camp Guilford Bower (CGB) in I927, and it formally opened a year later. Located on 3I4 acres near New Paltz, CGB enrolled girls and boys ages 8 -I8 each summer on its property. Its director, Shelton Hale Bishop, recruited campers from across the United States by visiting several "prominent cities of the middle West and South" and advertising in the New York Amsterdam News, encouraging parents to send their children for the entire summer. Johnson attended CGB for four years, advancing from camper to counselor. Gilford Bower offered its campers "various nature, crafts, or dramatic activities during the mornings and . . . swimming or games during the afternoons." The coeducational camp ended in 1932. Thereafter, St. Philip's operated separate sessions, one month for each gender. Several church members supported this change, indicating they "could not see the [continued] coed operation." Johnson simply reported, "This didn't work." Four years later, unable to continue funding its operation, St. Philip's sold the property to the Children's Aid Society, citing the financial effects of the economic depression as the main cause. ${ }^{64}$

Marcia Chatelain discusses the role that camps played in the lives of African American girls. She notes that "camping was an unquestionable pleasure of childhood, in the United States," when African American children began attending. Camping provided many American children their "first experience of community beyond their immediate family and home neighborhoods." 65

63. Paris, "Adventures of Peanut and Bo," 88, 85-86.

64. "Mildred Goes to Camp," 2, I, 7, Admin Modern School box, TMS Collection; https:// digitalharlemblog.wordpress.com/2018/07/20/summer-camps-for-I920s-harlem/; Camp Guilford Bower, Director's Report Season 1929, October 8, I929, 88-93, Director's Report Season I93I, October I3, I93I, 225-29, Director's Report Season I932, September I2, I932, 304-9, I929I932, vol. 8, St. Philip's Episcopal Church Records Collection, Manuscripts Archives and Rare Books Division, Schomburg Center for Research in Black Culture, New York Public Library (hereafter SPEC Collection); "When We Began," "Mildred," "Lots of Children," 7, The Modern School box, TMS Collection.

65. Marcia Chatelain, South Side Girls: Growing Up in the Great Migration (Durham, NC, 2015), I32; "When We Began," "Mildred," "Lots of Children," I8, box The Modern Scool, TMS Collection. 
Similarly, Paris argues that summer camp experiences "consolidate[d] the notion of childhood as a time apart, at once protected and playful." Given the nature of race relations in the United States, it is likely that camp founders did not envision African Americans having a need for recreation activities. The need for Harlem's children to have camping experiences grew in importance and relevance due to population increases attributable in part to the effects of migration and limited "access to recreational opportunities" in Harlem. Given the discriminatory administration of government services, particularly during the New Deal era, camp advocates were vigilant in their efforts to ensure African American children had access to this experience that provided them an opportunity to participate in activities "deemed quintessentially [a] part of American childhood."66

Johnson and her friends decided to work at Camp James A. Farley, a camp for "underprivileged children," in I933. The FAF purchased the campsite, located five miles from Poughkeepsie, in 1929. The summer of 1933 at Farley was laden with hardships, as the camp lacked resources, and facilities for campers were substandard. While Johnson toiled at Farley, a friend at Camp Atwater wrote her inquiring, "Are you having a good time? I'm having a swell time as Atwater is grand this year." Atwater, located in Massachusetts, was the first summer camp founded by African Americans and run for their children. Johnson was paid \$48.00 - \$6.00 per week - instead of the \$50.00 that was initially agreed to for the summer's work. She viewed being shorted \$2.00 as an insult and resolved to "never work for anyone else," a bold declaration for anyone, especially a nineteen-year-old African American woman. Johnson knew her worth and chafed at the fact that a contracted agreement was not honored. She ultimately suspected that race played a role in her final compensation. ${ }^{67}$

After exposure to various camping experiences, and because of her interest in teaching, Johnson decided to create her own camp the following summer. She envisioned providing an engaging summer experience for African American children. In her words, "Camps . . . were only for the underprivileged child.” In I934, Johnson concluded that there were limited camping opportunities for middle-class children and noted that those not affiliated with a church were "a rarity." Seeing the need, Johnson decided that middle-class children were the population for her camp. Her experience at Farley was vastly different from her experience at CGB and highlighted the difference

66. Chatelain, South Side Girls, I33, I46, I64.

67. See "Summer Camps for I920s Harlem," https://digitalharlemblog.wordpress.com/20I8 /07/20/summer-camps-for-I920s-harlem/; postcard dated August 24, I933, addressed to Mildred Johnson, The Modern School box, "Mildred Goes to Camp," 6, 4, Admin Modern School box, "When We Began," "Mildred" "Lots of Children," I8, The Modern School box, TMS Collection. 
in provision of an adequate summer camp experience tied to one's race and ability to pay. In this camping experience, Johnson witnessed firsthand the systemic deficits built into the structure of American society based on class differences and sought to meet the need. ${ }^{68}$

Describing the founding of Camp Dunroven, Johnson observed that it was "no more illustrious than the start of [TMS]." Seven parents agreed to entrust her with their children for the summer. Despite the fact that she was just twenty years old, Johnson knew that her decade of camping and summer work at Camp Farley had prepared her to run a camp. "I had experience in all types of camps," she reported, and attended camping courses offered at Columbia University. Johnson named her camp Dunroven because, as she recalled, campers "always felt that when we reached the camp we were 'done roving." She even composed a ditty for them to sing as they returned from their daily outdoor activities; "Dunroven - When I have been all around and am ready to settle down-'I'm through roving,' I'm Dunroven."69

The camp was located in her parents' summer home "in the hills near Greenwood Lake, New [York]," which was spacious enough to house the seven enrolled campers..$^{70}$ During the first summer, Johnson charged $\$ 7.00$ per week per camper, while other camps charged $\$ \mathrm{IO} .00$. Fees were used to purchase necessary supplies and secure rentals, and after expenses were paid, $\$ 6.50$ remained to feed campers during its first week. Dunroven was staffed with a team of three. Nadine Owens Robinson, a long-time family employee, served as cook; Nora, Johnson's mother, "kept the accounts"; and Johnson engaged campers in various activities and adventures, including "a very full program of crafts" and an "out-of-door festival" for weekend visits by parents and other guests. Johnson knew the territory well and drew on her Ethical Culture education, TTD training, ingenuity, and creativity to augment the camp's resources. Johnson's campers also had American Indian lore and dance. They "learned camp songs and returned to their homes filled with camp-lore." She learned American Indian lore firsthand from her father, who, in I921, was "made [a] Sub-Chief of the Iroquois Indian Reserve, Caughnawaga Province, Quebec, Canada."71 Reporting in 1938, New York Amsterdam News reporter Thelma Berlack-Boozer noted that "Miss Mildred Johnson, head of The Modern School in Manhattan . . . has

68. "Mildred Opens Dunroven," 7, The Modern School box; "When We Began," "Mildred" "Lots of Children," II, The Modern School box, TMS Collection.

69. Ibid.

70. "Mildred Opens Dunroven," 7, The Modern School box, TMS Collection.

7I. Ibid., 7-8. Personal communication with K. Melanie Edwards, Mildred Louise Johnson Edwards's daughter, on July I4, 20I9; "J. Rosamond Johnson,” I, box 2, ser. 3, folder II, JRJ Papers; "Impressive Rites for J. Rosamond Johnson," New rork Amsterdam News, November 20, I954, JRJ Papers. 
conducted a summer camp for children at Greenwood Forest Farm an exclusive resort enclave in New York." Further, she informed readers "many of the youthful campers attend Miss Johnson's school during its regular session." ${ }^{2}$

During World War II, Dunroven provided services to parents who were employed in wartime industries. Johnson recalled, "Most of my children's parents were a part of the war picture, so we became an essential part too, because we were caring for children so parents could work in war factories." New York City-area shipyards, military bases, and the education institutions actively supported wartime preparation - the production of weaponry and warships, and training of servicemen and women and volunteers. After the United States entered WWII, New York City residents became preoccupied with concerns about submarine attacks along the shore. The fear of German attacks on the United States escalated in 1942 with the sinking of the U.S.S. Lafayette in New York City. That summer, Johnson extended the campers' stay at Dunroven and allowed TMS parents to send their children there as a safety measure. By keeping the children at camp, Johnson's action offered parents the opportunity to support the country during this crisis. African Americans' work in war industries was an expression of patriotism and supported the "Double V" campaign. ${ }^{73}$

Dunroven's popularity attracted children from as far away as Chicago and the West Indies, as did CGB. Because of increasing demands for enrollment, Dunroven quickly outgrew the family owned property in upstate New York and relocated two additional times. Its second location was Joe Louis's former training camp, near President Franklin Delano Roosevelt's family home in Hyde Park. Its final location was near Pine Bush, about seventy-five miles north of New York City. There, Johnson purchased surrounding property and eventually owned forty acres (fig. 2). ${ }^{74}$ Johnson described the bucolic setting: "the house sat on two acres of land with open fields all around it. It was within walking distance of a stream. And we housed our horses in the field near[by] ... [we had an] out-of-door spot for campfires, baseball fields, a spot for festivals, areas for picnicking and outside cooking." 75

72. "Greenwood Lake May Become East's Most Fashionable Summer Colony," New York Amsterdam News, July 23, 1938.

73. "Mildred Opens Dunroven," 8, The Modern School box, TMS Collection; Zachary Keck, "The Time America Thought the Nazis Bombed New York City," National Interest, https:// nationalinterest.org/blog/the-buzz/the-time-america-thought-the-nazis-bombed-new-york-city $-21095$.

74. "When We Began," "Mildred," "Lots of Children,” I3, The Modern School box, TMS Collection; Camp Guilford Bower, Director's Report Season I929, October 8, I929, 88-93, Director's Reports Season I93I, October I3, I93I, 225-29, Director's Report Season 1932, September I2, I932, 304-9, I929-I932, vol. 8, SPEC Collection.

75. "Mildred Opens Dunroven," Io, Admin Modern School box, TMS Collection. 


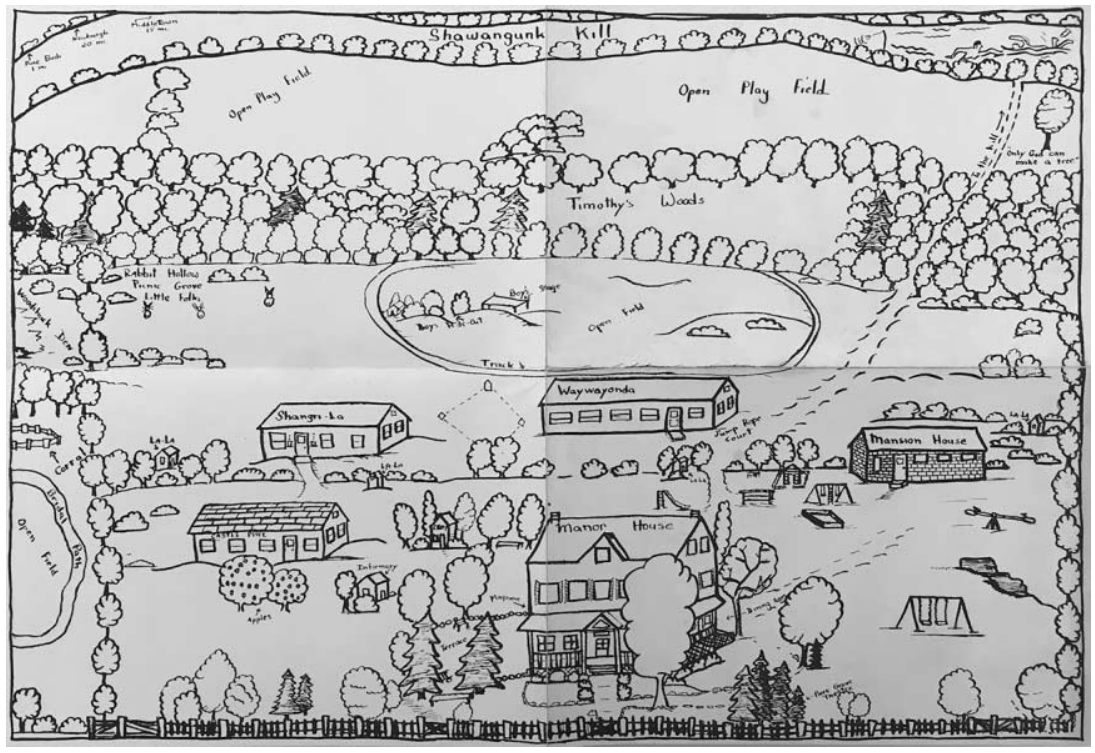

Figure 2. Photo of a hand-drawn map of Camp Dunroven's Pine Bush, NY, location, I940s or I950s. Photograph courtesy of The Modern School Collection, Manuscripts Archives and Rare Books, Schomburg Center for Research in Black Culture.

Since her camp had "run quite successfully," Johnson returned to New York City in August 1934 already having thought through the process of creating a school so she could "have someplace to practice teach." ${ }^{76}$ The founding of Camp Dunroven was Johnson's first experiment in providing education-based childcare that would last a quarter-century. Her work at TMS was born of a desire similar to the founding of Camp Dunroven. Johnson wanted African American children to have a summer camp experience that exposed them to the outdoors providing an affirming and supportive environment as well as an educational experience. Her next venture lasted for sixty-five years and educated generations of Harlem's students. Dunroven remained in the Pine Bush area for twenty-one years until it closed after twenty-five camp seasons of successfully serving an integrated community of campers.

Writing about her life in 1993, Johnson explained that her work at TMS was an outgrowth of being a "mother figure' for four weeks in the summer" and then "living with them and being responsible for educating them" at TMS. She continued, indicating this experience of living in close proximity to a number of her students for extended periods of time "flavored The Modern School

76. "Outline of TMS," 3, The Modern School box, TMS Collection. 
in a different manner than most [other] institutions." "77 Adina Back used a similar phrase, "motherwork," to describe Black women who "bridged the boundaries between public and private" spheres, noting that in the African American community "motherhood was hardly a monolithic identity" as women took on several leadership roles. Johnson's statement above illustrates this concept because of her role as a teacher at the TTD, her work at Dunroven, and the unofficial "mother" role she filled by allowing TMS students to live in her home. She was both teacher and mother to children in her care, as well as a civically engaged leader. ${ }^{78}$ Creating TMS was an early display of activism and agency prefiguring the actions of mothers who demanded better schooling options for their children in I950s and I960s Harlem.

\section{FOUNDING THE MODERN SCHOOL, 1934}

It was an accident of the times and my own educational background that forced me to open a private school; a private school predominantly for Black children. ${ }^{79}$

When Johnson opened TMS in 1934, Harlem's schools were almost completely segregated by race. A 1954 Public Education Association report noted this was the case for 7I percent of New York City's schools. During the Great Depression, the population of African Americans in Manhattan increased by more than 175,000 , due to migration, bringing the total population to almost 200,000 . From the beginning of the twentieth century through the start of the Great Depression, African Americans in New York City were able to attend integrated schools in their communities. However, because of the increasing African American population and changing residential living patterns, Harlem's schools became more segregated. Additionally, few, if any, schools had been built in the area since the turn of the century. Harlem had twenty-one elementary schools and one high school to serve its students. ${ }^{80}$

77. "When We Began," "Mildred" "Lots of Children," I8, The Modern School box, TMS Collection. Several students boarded with Johnson in her home due to family circumstances.

78. Back, "Exposing the 'Whole Segregation Myth,", 66, 79.

79. "Outline of TMS," I, The Modern School box, TMS Collection.

80. Jennifer de Forest, "The 1958 Harlem School Boycott: Parental Activism and the Struggle for Educational Equity in New York City," Urban Review 40 (March 2008): 23, 25; Melissa Weiner, "All the News That's Fit to Print: Silence and Voice in Accounts of African American Protest," Research in Social Movements, Conflicts and Change 3I (20I0): 312; Gerald Markowitz and David Rosner, Children, Race, and Power: Kenneth and Mamie Clark's Northside Center (Charlottesville, VA, 1996), 92-94. 
The summer of I934 was eventful for Johnson as she opened Dunroven and planned for TMS. Johnson recalled that she decided not to student teach "in the 'nice Catholic School." Upon learning that the retired rector of St. Philip's Episcopal Church, Father Hutchens Chew Bishop, had vacated "the brownstone-type rectory" in I933, Johnson took action. The church, established in 1818, was "an offshoot of Trinity Church." Like many churches during the period, St. Philip's moved several times. Prior locations included Mulberry Street, 25th Street in the Tenderloin District until I9Io, and then Harlem, following its parishioners. ${ }^{8 \mathrm{I}}$ Learning of the vacant parish house, Johnson requested a portion of the rectory to start her school. Her first students were between two and a half and six years old. The negotiated agreement was to pay the church Io percent of TMS's income. Finding initial funding for TMS was a challenge given the country's economic condition. Johnson approached Miss Donohue, her former TTD teacher and first student teaching supervisor. Together, they discussed Johnson's plan for completing her second and final student teaching appointment. Donohue supported Johnson by drafting "some literature to tell about the school." She also assisted with its design and paid for printing the 1934-1935 brochure. ${ }^{82}$

Johnson named her school The Modern School of Harlem, because "it was to be a modern school" located in Harlem. Perhaps she chose an aspirational name because she envisioned a day when her students would no longer be subjected to segregation or racial discrimination. In deliberately naming the school, Johnson foresaw a day when African Americans would be recognized as US citizens. For Johnson, this, coupled with the education her students received, represented a "modern" way of living and being, versus the experience of many African American citizens at that time. The school would help students reach their highest potential (fig. 3). ${ }^{83}$

Twenty-year-old Mildred Louise Johnson confidently opened her private school in Harlem at 2I7 West I33rd Street, on September 27, 1934, with eight of her friends' young children as her first "pupils," representing a mixture of races and social classes all engaged in learning and discovery. She observed,

When the school started, I enrolled eight boys and girls. Four were from professional families: an undertaker, a doctor, a lawyer, a musician. The other four were: the child of a domestic, a social worker with a child of mixed marriage, a neighborhood store-keeper's child, white-Jewish, and

8I. Anderson, This Was Harlem, 23; "St. Philip's Church,” https://www.stphilipsharlem.org /history; Markowitz and Rosner, Children, Race and Power, 92-94.

82. "Lots of Children, or A Story of Mildred," Io, Admin Modern School box, TMS Collection. 83. Ibid., Io. 


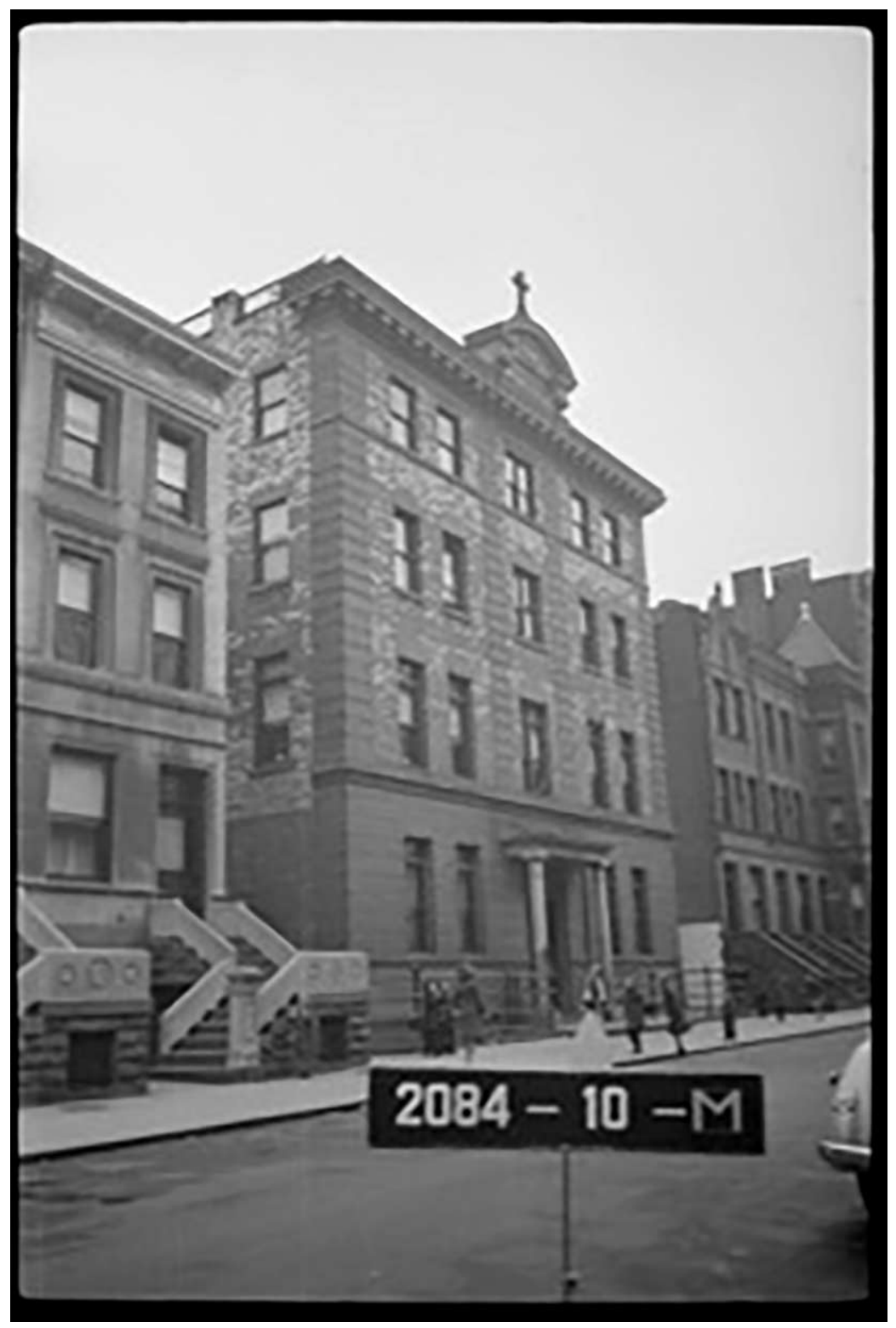

Figure 3. Image of 539 W. 152 nd Street, circa the I940s. This property was purchased by Mildred Johnson in 1953. Photograph courtesy of NYC Municipal Archives. 
the child of a Latin background whose parents were seasonal workers in the garment district. ${ }^{84}$

When Johnson opened TMS, she was nearing completion of her studies in Ethical Culture's TTD. In creating the school, she provided herself the opportunity needed to complete the second TTD student teaching requirement. She declared, "I was proving to myself, and any other interested individuals, the fact that, given the same opportunities, exposed to the same activities, Black children are as bright, as creative, as scientific, as musical, [and] as mathematical as any ethnic group. Given an opportunity and proper teaching, they will read as well as any of their peers." 85

The 1934-35 “Announcement of The Modern School” indicated that it would educate children from prekindergarten through primary school. Its staff of five included Dorothy Wright, a psychologist; Nora E. Johnson, Mildred's mother, as hostess; and Virginia Stevens, a nurse. Titles were not provided for Mildred Johnson or Xenia Kibrick. ${ }^{86}$ Like Johnson, Kibrick was likely another student in need of a training placement. A board of directors governed TMS, as it was a private school. Its first board consisted of Vivian T. Thayer, educational director at Ethical Culture; James Weldon Johnson, her uncle; Shelton Hale Bishop, the new rector of St. Philip's Episcopal Church; Ellen K. Donohue, registrar; Bessye Bearden, civic activist; Mabel P. Jenkins, St. Philip's social service department's director; and Joseph A. Baer, administrative associate at Ethical Culture.$^{87}$ TMS's aims and purposes were clearly stated:

The School is established to provide a program which offers to the child opportunities to become identified with life, and so to develop to the fullest extent in body and mind, thereby becoming a healthy, effective[,] and happy member of society.

The school will be a small community where each one, teacher, pupil[,] and parent realizes his share of responsibility.

The school encourages the level of qualities[,] which make for effective group living - among these the ability to accept and give helpful criticism,

84. "Outline of TMS," 4, The Modern School box, TMS Collection.

85. "A Few Incidents from The Modern School (1934-)," 5, The Modern School box, TMS Collection.

86. Xenia Kibrick graduated from Teachers College, Columbia University, in 1938, with a bachelor of science degree; see Columbia University, Catalogue 1938-1939, https://archive.org /details/cataloguer938colu/page/n2I9.

87. Weisl, "The Modern School in Harlem," TMS Collection; Yearbook of the Department of Teacher Education (New York, I937), 7, box 52, folder 15, ECFS Collection; "Mabel P. Jenkins, 98 Former Social Worker," New York Times, March I9, I99I; “Teacher Training Department Ethical Culture Schools," 3, box 157, folder 20, ECFS Records. 
solve problems in social situations, and to contribute actively to group enterprises. $^{88}$

Annual tuition at TMS was set at \$I00.00 in I934, payable in installments. At its founding, TMS was the only Black owned and operated private school in New York City and remained so until 1939 when a second school opened. In I948, a third school joined this small group of private schools, founded and run by African American women in New York City. Johnson charged tuition significantly below that charged by White private schools in the city. Her alma mater charged a tiered tuition for its elementary students for the $193^{1-32}$ academic year. Prekindergarten and kindergarten cost $\$ 325.00$ per child, and the first through third grade tuition cost $\$ 385.00$ per child. As registrar, Donohue accepted admission applications as well as Johnson, and prior to admission, home and grading interviews were conducted to determine each applicants' academic standing. The school year ran from September through May, with holiday breaks. ${ }^{89}$

Johnson's successful administration of TMS that first year fulfilled the TTD program requirement and she received her diploma on June 4, I935. During this year, Wright and Donohue supervised Johnson's work. While the school functioned on revenue generated from tuition, in its first year Algernon Black, leader of the Society for Ethical Culture, contributed \$100.00 to Johnson's school, which paid for two rooms of furniture. ${ }^{9 \circ}$ In the school's second year, 1935-1936, there were four staff members, including Johnson: Wright remained as the psychologist; Anna Smalls Murphy and Dr. Samuel F. Jenkins joined the staff. Board membership remained unchanged. Annual tuition remained \$100.00 for prekindergarten and kindergarten; however, tuition was raised to $\$ 180.00$ for all primary grades. Parents with modest incomes who chose to provide their children a private school education made a personal sacrifice, hoping this education would open more opportunities for their children. This sacrifice reflects their belief in the education and the opportunities that a private school education offered. The "Announcement of The Modern School

88. "Announcement of the Modern School of Harlem I934-1935," 3, box I22, folder Modern School of Harlem, JWJ Collection.

89. Ibid., 4, 2; "General Announcement of the Ethical Culture Schools, I93I-I932," 2I, box 157, folder I6, ECFS Records; Audrey Edwards, "They Made It Happen,” Black Enterprise (May 1980): 33-37; "Geraldyn Dismond Says: Three Smart Girls to Be Feted," New York Amsterdam News, January I, I944, box I22, The Modern School folder, JWJ Collection.

90. Weisl, "The Modern School in Harlem," TMS Collection; Wolfgang Saxon, "Algernon Black, Leader of Society for Ethical Culture, Is Dead at 92," New York Times, May II, I993. 
I935-1936" noted that the school was under the direction of "Mildred L. Johnson, I935 graduate of the Ethical Culture Progressive Training School."9r

TMS remained at the rectory two years before making several moves and finally settling in a five-story building that housed all grades, kindergarten through sixth. Due to its growth between I934 and I936, TMS had to find a new home. When the school relocated to 428 West I54th Street between Amsterdam and St. Nicholas Avenues in 1936, its enrollment had reached twentyfour students, and there were three teachers. ${ }^{92}$ Due to problems with the building's maintenance, Johnson moved the school into the home of one of the parents in 1938, also located on West I54th Street. At this location, the school had access to two floors and use of the yard for recreation. The staff increased to four teachers and a cook, and TMS had use of a station wagon for transportation. ${ }^{93}$

Two years later, TMS moved to 4II West I54th Street. With financial assistance from her father, the building was purchased and remodeled to accommodate up to IOo children. At the time of their move, TMS enrolled fifty students. Planning for expansion to accommodate the "upper elementary grades"fourth through sixth grades, a second site was identified and secured at 437 West I62nd Street. Student enrollment totaled I50, with twelve classroom teachers, two members of the kitchen staff, two front office staff, and transportation facilities. This building met the needs of the growing student population for several years. However, in 1953, the year before her father's death, Johnson purchased a five-story building, with forty-five rooms, at 539 West I52nd Street, from the Catholic Institute of Mercy. This would be TMS's final home. At that time, its enrollment exceeded 200 students. ${ }^{94}$

Johnson commented that during its early years, TMS's neighborhood was "quite a mixed one." Because she served the children and families in Harlem, the diversity of the neighborhood was reflected in its enrollment from its inception, and this was also true of her camp. Johnson's Ethical Culture experience

9I. "Ethical Culture Schools: Mildred Louise Johnson," Teacher Training Department diploma, June 4, I935, The Modern School box, TMS Collection; "Graduation Exercises Teacher Training Department," 2, The Modern School box, TMS Collection; "Announcement of the Modern School of Harlem I935-1936," 2 - 4, box I22, folder Modern School of Harlem, JWJ Collection.

92. "Mildred Johnson's Modern School Children are Participants," periodical and date unknown, Admin Modern School box, TMS Collection.

93. "Background Data Re: Mildred Louise Johnson Edwards, October 1962," I, The Modern School box, TMS Collection; Weisl, "The Modern School in Harlem," TMS Collection.

94. "Background Data Re: Mildred Louise Johnson Edwards, October 1962," 2, The Modern School box; Weisl, "The Modern School in Harlem," TMS Collection; "Education: New Yorker Pays \$70,000 for School Quarters,” fet Magazine, February 25, 1954; Betty Granger Reid, "Conversation Piece," New York Amsterdam News, May 23, 1970, box 122, Modern School of Harlem folder, JWJ Collection. 
was evident in her teaching as TMS's educational model "follow[ed] the plan of the Ethical Culture Schools." She relied on "the project method" in all her classes and focused on individual student progress, as she believed this was "the most important factor." While each child was "allowed to develop according to his own needs and ability," Johnson and her faculty worked to ensure students met New York State education standards." Her teachers emphasized "creative work" - writing poetry, art, creative arts, and story telling — and each child was able to spend time doing work that interested them. ${ }^{95}$

When the school was opened, “from nine until three o'clock Mildred was the mother, teacher, nurse[,] and friend for all the many children of The Modern School." In creating and running TMS, Johnson finally fulfilled her wish to have "lots of children." This desire stemmed from being an only child who spent most of her time alone or socializing with adults where she was the center of attention. In 1934, creating a school that catered to preschool children was a rarity. Johnson recalled that those that did exist "were part of a parochial school or a separate nursery group organized for day care, and not for education."96

\section{COMMUNITY AND PROFESSIONAL INVOLVEMENT}

Johnson's long-term leadership of the school was one example of her contribution to the Harlem community. In addition to her work at St. Philip's Episcopal Church, she volunteered with the Girls Club of the Children's Aid Society. In the I970s Mildred told an interviewer, "A woman who could teach would never go hungry. Teaching is a bread and butter job." Her education, formal and informal, allowed her to work in a variety of organizations, including the Hudson Guild and the Henry Street Settlement's fine arts department. ${ }^{97}$ Johnson also worked on several research projects in the Harlem community. Working with pediatrician Thomas W. Patrick, she completed a survey that highlighted the need for preschool facilities north of 96th Street. Jessie Stanton, an advocate of progressive education and a nursery education authority, and Mrs. William Paley, a socialite and philanthropist, became interested in establishing "a Philanthropic nursery in East Harlem." The Neighborhood Day Nursery resulted from this effort, opening at 5 West II3th Street, on November $7,1943 .{ }^{98}$

95. Weisl, "The Modern School in Harlem," TMS Collection.

96. "Lots of Children, or A Story of Mildred," II-I2, Admin Modern School box, TMS Collection; Michel, "History of Child Care in the U.S.," 5.

97. Juanita Isabel Coleman, "Once a Teacher: Biography of Mildred L. Johnson Edwards, Black Educator" (master's Thesis, Bank Street College), 6; and "Biography: Compiled by John Van Putten," 2, The Modern School box, TMS Collection.

98. "Biography: Compiled by John Van Putten," 2, The Modern School box, TMS Collection; Michel, "History of Child Care in the U.S.," 3, 5; Morris Kaplan, "Jessie Stanton, 89, Expert on 
She also worked on research projects associated with higher education institutions in New York City, including Teachers College, New York University, New York Medical College, Hunter College, and the Institute for Developmental Studies. These studies focused on exploring "the situation of the Black child in a controlled group setting." Her TMS work received praise from national, state, and local officials, including Ronald Reagan, New York governor Mario M. Cuomo; South Carolina governor Richard W. Riley; New York senator Basil Paterson, and New York mayor Edward I. Koch. Johnson's work at TMS was examined and celebrated in local newspapers, including the New York Amsterdam News, the New York Age, the New York Post, and the New York Daily News. fet and Essence magazines covered her social activities, as did Martha's Vineyard's local newspaper, the Vineyard Gazette. ${ }^{99}$

Johnson lent her time and energy to organizations that advanced causes that she believed in and that advanced educational opportunities for her students. To that end, she held memberships with the National Association of Nursery Education, Pre-School Association, American Society of Composers, Authors, Publishers, American Guild of Authors and Composers, Save the Children Foundation, Jack and Jill of America, English Folk Dance Society of America, and the New York Chapter of Girl Friends, Inc. As a youth, Johnson was a member of the Junior League of the NAACP under the direction of Bessye B. Bearden (a journalist and civic activist who served on TMS's board of directors). As a result of her success leading TMS, Johnson was a regular participant in the Progressive Education Association's (PEA) regional conferences, participating on panels with Ethical Culture's educational director, Vivian T. Thayer. She also served on the Stephen Wise Adoption Committee and Fieldston's Curriculum Evaluation Committee. During her lifetime Johnson composed and produced more than fifty unpublished plays and musicals for children, as well as a book of poems for children, Painting with Words. ${ }^{\text {10o }}$

Nursery Schools, Dies," New York Times, May I8, I976; Enid Nemy, "Dorothy H. Hirshon, 89, Dies; Socialite and Philanthropist," New York Times, January 3I, I998; "Model Day Nursery Added to Community," New York Amsterdam News, November I3, I943.

99. "Biography: Compiled by John Van Putten," 2, The Modern School box; Letter dated May 20, 1984 from Ronald Reagan; Letter dated May I7, 1984 from Mario M. Cuomo; Undated letter from Richard W. Riley; Letter dated April I7, 1984 from Basil Paterson; Letter dated May 20, I984 from Edward I. Koch; The Modern School box, TMS Collection.

IOo. "Biography: Compiled by John Van Putten," 2-3, The Modern School box, "Essence Woman," Admin Modern School box; Vinal H. Tibbetts to Mildred Louise Johnson, January 25, I944, Admin Modern School box, TMS Collection; "To Be Rewritten," I, The Modern School box, TMS Collection. Stephen Wise is the father of Justice Justine Wise Polier, who presided over the case of five students and parents in the Harlem 9 case. 


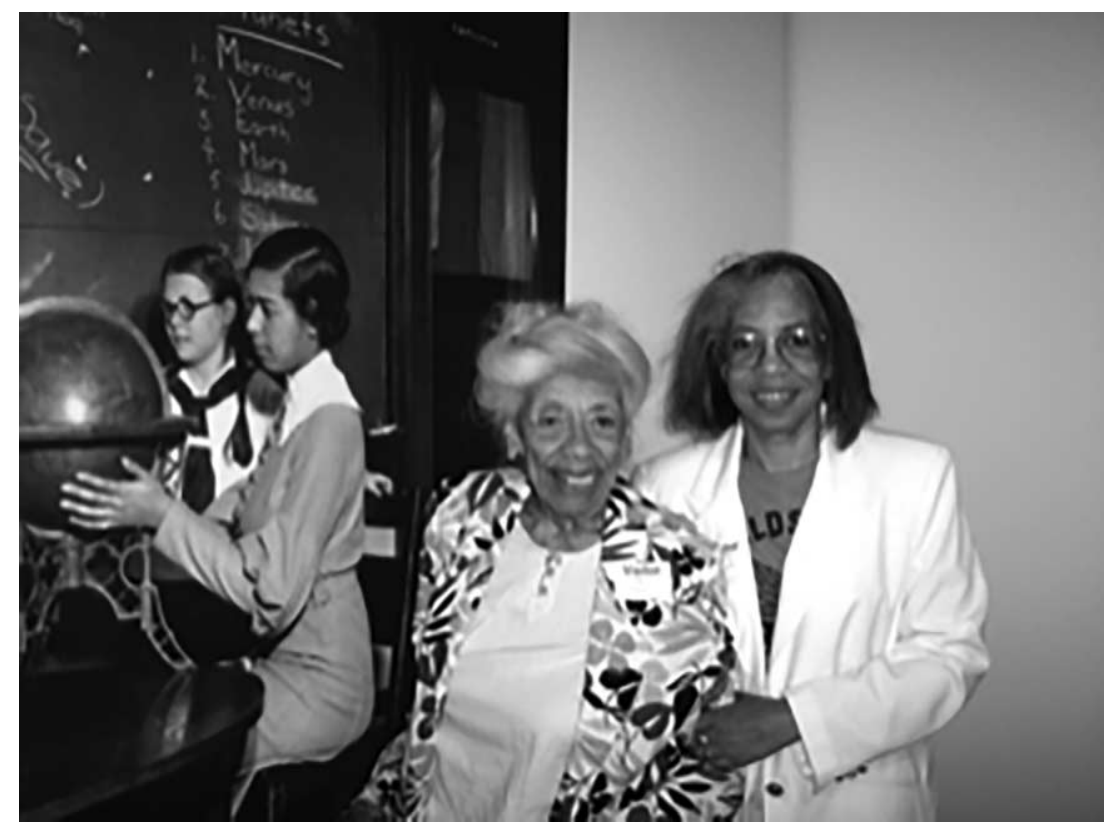

Figure 4. Photo of Mildred Johnson and K. Melanie Edwards in front of a photograph of Johnson instructing an Ethical Culture student while enrolled in EC's TTD. Photograph courtesy of K. Melanie Edwards's personal collection. Color version available as an online enhancement.

While Johnson devoted the bulk of her life to Camp Dunroven and The Modern School, she did have a personal life. She married Hedley Vivian Edwards, of Nassau, Bahamas, on April 22, I95I, at St. Philip's Episcopal Church, with Father Shelton Hale Bishop presiding over an elaborate ceremony attended by more than 600 guests. The Edwardses had one daughter, K. Melanie Edwards (fig. 4), who, like her mother, is an alumna of the Ethical Culture and Fieldston School. Also, as did her grandmother Nora Johnson, Melanie assisted Johnson's life's work at TMS, serving as a teacher and managing her mother's business affairs. ${ }^{\text {Ior }}$

\section{GONGLUSION}

Johnson's work continues the tradition of African American women educators who established schools that provided a quality education for African American

IOI. "Background Data Re: Mildred Louise Johnson Edwards, October I962," The Modern School box, "Mildred L. Johnson" (undated and untitled document), The Modern School box, TMS Collection; Gerri Major, "Society Travelogue," fet, April II, I963; "Register 1950 DecemberI952 January,” April 21, I95I-April 26, I95I, box I4, folder I4, SPEC Records. 
children. Like Laney, Brown, Bethune, and Burroughs, Johnson leaves an educational legacy that continues on through the lives of its alumni. Despite leading her school for sixty-five years in Harlem, her work has remained largely unknown to historians. Why doesn't the public know more about Mildred Louise Johnson's life, work, and legacy? Margot Lee Shetterly poses a similar question in her epilogue to Hidden Figures. In addressing the question, she references the role of "legalized segregation, [and] racial discrimination," noting that they made it possible to obscure or pass over the accomplishments of African American women. Shetterly notes, "each of us should be allowed to rise as far as our talent and hard work can take us." "'o2 Johnson and Shutterly's subjects did just that. They pursued their interests and sought to develop and contribute their talents to a shared American history.

Legalized segregation and discrimination challenged African Americans to be creative in building and sustaining their communities and culture. Johnson used education as her means to generate change in Harlem. She exposed her students to the basics and provided expanded curricular offerings to help students develop an appreciation of the arts, various cultures, and African American history. Johnson's general omission from history can perhaps be most directly linked to the lack of an existing archive. This is now being remedied, as some TMS papers are housed at the New York Public Library. The lack of an archive calls into question how we as historians practice our craft. While archives are essential to our work, often the histories we need to tell are not be found there. Johnson and her work are visible in various periodicals and become visible when engaging in conversation with longtime members of the Harlem community, especially those involved in social services, daycare, nursery schools, and K-I2 education. A number of people remember the school and its work, as do its alumni, parents, and teachers.

After interviewing Johnson in I944, her former TTD classmate Joan Hamburg Weisl noted that it is necessary to "follow the development of this unusual school to determine the progress in the cultural and educational background of these ... citizens who will be influenced by[,] and exert influence, on the world to come." ${ }^{\text {ㅇ }}$ While the school no longer exists, research on TMS and its impact is in its formative years. Future research will focus on the items Weisl mentioned above to fully unearth the story of Johnson and TMS as told by those who experienced it. I have speculated here about parents' reasoning for sending their children to this school; however, hearing parents' reasoning for choosing to send their children to TMS is a rich source of information to explore. Further, the accomplishments of the school's alumni can reveal dimensions of 
the outcomes of Johnson's TMS work. What will be most revealing is telling TMS's history as the school changed over the six and a half decades that it served the Harlem community. Mildred Louise Johnson was an education pioneer and a savvy businesswoman. Her life's work offers a model of what successful education for African American students in an urban setting looked like during the twentieth century. 